\title{
THE GROWTH AND VIABILITY OF STREPTOCOCCI OF BOVINE AND HUMAN ORIGIN IN MILK AND MILK PRODUCTS * \\ DaVID JOHN DAVIS
}

(From the Department of Experimental Medicine, University of Illinois, Chicago, 1ll.)

While investigations were being made in connection with the epidemics of sore throat in Chicago, in Batavia, Ill., and in Jacksonville, Ill., questions were often asked whether cream, sour milk, buttermilk, ice-cream, butter and cheese were concerned in the transmission of the infecting streptococci. Since these questions have not been carefully studied it was thought worth while to make some observations bearing on them.

So far as we know, all streptococci causing epidemics of septic sore throat have been of the hemolytic variety. $\dagger$ This is certainly true of the more recent epidemics in Chicago, Boston, Baltimore, Jacksonville (IIl.), Concord, N. H., and Wakefield and Stoneham, Mass., in which this particular property was carefully noted. In some of the epidemics, especially the earlicr epidemics in England, this property was not investigated, but there is no reason whatever for thinking that any other sort of streptococci was responsible, since the characteristics mentioned in each instance lead one to believe they likewise were of this variety. These statements refer to the organisms isolated directly from the throat, blood, exudates, etc. of persons and also to strains isolated from suspected cows.

While these streptococci are included in the hemolytic group, all are not exactly alike in other particulars. In the reports of the Chicago epidemic, attention was called to the fact that from the blood and exudates, and at times from the throat, certain streptococci were obtained which were highly virulent and which were encapsulated; they produced a clear but distinctly narrower zone of hemolysis than

* Received for publication July 6, 1914.

+ When the term hemolytic property is used in this paper it refers to the appearance of the colonies on human blood agar plates. Those organisms are called hemolytic which cause a distinct clear zone of hemolysis about the colonies when incubated at $37 \mathrm{C}$. for 24 hours. Many streptococci may produce a narrow greenish, grayish or brownish zone in which, especially after two or more days at times, some clearing of the media may occur. Such strains, however, are not considered true hemolysers and are referred to as nonhemolytic, 
the common hemolytic streptococci and they also formed a more spreading and a more mucoid colony on blood agar plates. These observations were confirmed by Stokes and $\mathrm{Hachtel}^{1}$ in their study of the Baltimore milk epidemic. Now it is possible to cause the ordinary hemolytic streptococcus to take on the properties in question by animal passage. I have already expressed myself on this point, ${ }^{2}$ stating that probably the differences noted may be simply one of virulence; for all of the strains of the moist encapsulated variety have been highly virulent. This is not true of the ordinary strongly hemolyzing strains, some having a low degree of virulence; tho many, it must be admitted, are also highly virulent.

The fact that hemolytic streptococci are concerned in the causation of epidemics of sore throat, centers our attention on this type of streptococci when attempting to trace the source of the infection to milk-stupply. On the other hand, there is no reason whatever for attaching importance to streptococci of the non-hemolytic variety so far as a study of the etiology of milk epidemics is concerned. This particular point, it seems to me, should be more generally appreciated, and in all studies on milk streptococci, the hemolytic property should be carefully noted. I call attention to this because not enough emphasis has been placed on this property in the general study of streptococci by many bacteriologists. The work, for example, of Heinemann ${ }^{3}$ on milk streptococci makes no mention of the hemolytic property and therefore is of little or no value so far as this point is concerned. Likewise, such an excellent recent work as that of Rogers and Dahlberg," in which a large amount of valuable information about milk streptococci is given, makes no mention whatever of the hemolytic property. Savage, ${ }^{\overline{3}}$ in his excellent studies on milk, also fails to mention this point when discussing streptococci and their relation to sore throat epidemics. Stowell, Hilliard, and Schlesinger ${ }^{6}$ admit that the hemolytic property is invaluable in the study of pathogenicity, but because it cannot be correlated with other characteristics, they do not consider it in formulating their groups of streptococci.

1. Public Health Reports, 1912, 27, p. 1923.

2. Jour. Am. Med. Assn., 1912, 58, p. 1852.

3. Jour. Infect. Dis., 1906, 3, p. 181 .

4. Jour. Agricul. Research, 1914, 1, p. 491.

5. Milk and Public Health, 1912, McMillan \& Co., London.

6. Jour. Infect. Dis., 1913,12, p. 144. 
So far as we know at present, any appreciable number of hemolytic streptococci found in cow's milk obtained carefully in sterile tubes directly from the cow's udder always means a diseased condition. Ruediger, ${ }^{7}$ among others, has especially called attention to this point. It is, of course, true that udder disease is often caused by nonhemolytic streptococci, but as already stated, so far as we know, these bear no relation to sore throat. I have examined many of these organisms and they have little or no virulence for animals. On the other hand, the hemolytic streptococci, that I have examined from the udder, are always pathogenic to some degree for animals and usually quite highly virulent. This does not mean that they all are pathogenic for man. We cannot ascertain this point, but the probability is, as pointed out by Savage, that only now and then is this true of such strains.

TABLE 1

Growth of Hemolytic Streptococci in Sterile Milk at Varying Temperatures

\begin{tabular}{|c|c|c|c|c|c|c|}
\hline Temp. & Organism & At Once & 3 Hours & 6 Hours & 20 Hours & 48 Hours \\
\hline \multirow[t]{2}{*}{$10 \mathrm{C}$. } & $\begin{array}{l}\text { S. hemolyticus, human.... } \\
\text { S. hemolyticus, bovine.... }\end{array}$ & $\begin{array}{l}1,100 \\
1,000\end{array}$ & $\begin{array}{l}1,300 \\
1,000\end{array}$ & $\begin{array}{r}1,400 \\
900\end{array}$ & $\begin{array}{l}1,300 \\
1,100\end{array}$ & $\begin{array}{r}1,000 \\
900\end{array}$ \\
\hline & S. lacticus............. & 1,500 & 1,500 & 1,200 & 1,800 & 2,000 \\
\hline \multirow[t]{2}{*}{$20 \mathrm{C}$. } & S. hemolyticus, human..... & 500 & 400 & 400 & 600 & 1,500 \\
\hline & 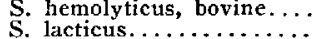 & $\begin{array}{r}150 \\
40\end{array}$ & $\begin{array}{r}20 \\
400\end{array}$ & $\begin{array}{r}18 \\
3,000\end{array}$ & $\begin{array}{r}100 \\
10,000\end{array}$ & $\begin{array}{r}500 \\
\text { many }\end{array}$ \\
\hline \multirow[t]{2}{*}{$26 \mathrm{C}$} & S. hemolyticus, hiuman.... & $\begin{array}{l}400 \\
800\end{array}$ & $\begin{array}{l}400 \\
700\end{array}$ & $\begin{array}{r}500 \\
600\end{array}$ & $\begin{array}{l}10,000 \\
10,000+\end{array}$ & many \\
\hline & 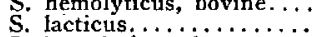 & $\begin{array}{l}800 \\
500\end{array}$ & 10,000 & many & many & many \\
\hline \multirow[t]{2}{*}{$30 \mathrm{C}$} & $\begin{array}{l}\text { S. hemolyticus, human.... } \\
\text { S. hemolyticus, bovine. }\end{array}$ & $\begin{array}{l}1,000 \\
400\end{array}$ & $\begin{array}{l}900 \\
600\end{array}$ & $\begin{array}{l}1,600 \\
1,000\end{array}$ & $\begin{array}{l}\operatorname{many} \\
6,000\end{array}$ & $\begin{array}{l}\operatorname{many} \\
\operatorname{many}\end{array}$ \\
\hline & S. lacticus. ............. & 500 & $10,000+$ & many & many & many \\
\hline \multirow[t]{2}{*}{$37 \mathrm{C}$. } & S. hemolyticus, human.... & 1,200 & 10,000 & 20,000 & many & many \\
\hline & $\begin{array}{l}\text { S. hemolyticus, bovine } \ldots \\
\text { S. lacticus.................. }\end{array}$ & $\begin{array}{l}1,400 \\
1,500\end{array}$ & $\begin{array}{l}8,000 \\
3,000\end{array}$ & $\begin{array}{l}\text { many } \\
\text { many }\end{array}$ & $\begin{array}{l}\operatorname{many} \\
\operatorname{many}\end{array}$ & $\begin{array}{l}\operatorname{many} \\
\operatorname{many}\end{array}$ \\
\hline
\end{tabular}

Two strains were used in nearly all the work discussed in this paper. One was an organism of the epidemic type isolated during the height of the Chicago epidemic from the blood of a fatal case. The other was isolated from an inflamed udder in pure culture. It showed the features of the epidemic type only after animal passage, but soon reverted to the ordinary hemolytic type. These organisms have maintained their properties and their virulence for animals unimpaired for over two years. They both ferment dextrose, lactose, saccharose and maltose, and do not ferment inulin, raffinose or mannite. Both are virulent for animals. In practically all of the following experiments

7. Science, 1912,35, p. 223 . 
these two organisms were observed side by side, and in no instance were any differences noted in their behavior. Furthermore, though carefully sought for, no alterations or transmutations of any kind were observed in these strains of streptococci or in several other strains tested, when growing or remaining in milk or in milk products.

In order to appreciate fully the influence of temperature on growth and before presenting other tables compiled from observations under varying conditions, there are given in Table 1 the results of growing, in sterile milk, strains of hemolytic streptococci of bovine and human origin and also a strain of the streptococcus lacticus at temperatures varying from 10 to $37 \mathrm{C}$. The figures in this table and also in the subsequent tables represent the number of colonies in a standard loop grown on plates of human blood agar.

TABLE 2

Growth of Hemolytic Streptococch in Commercial Milk at Various Temperatures

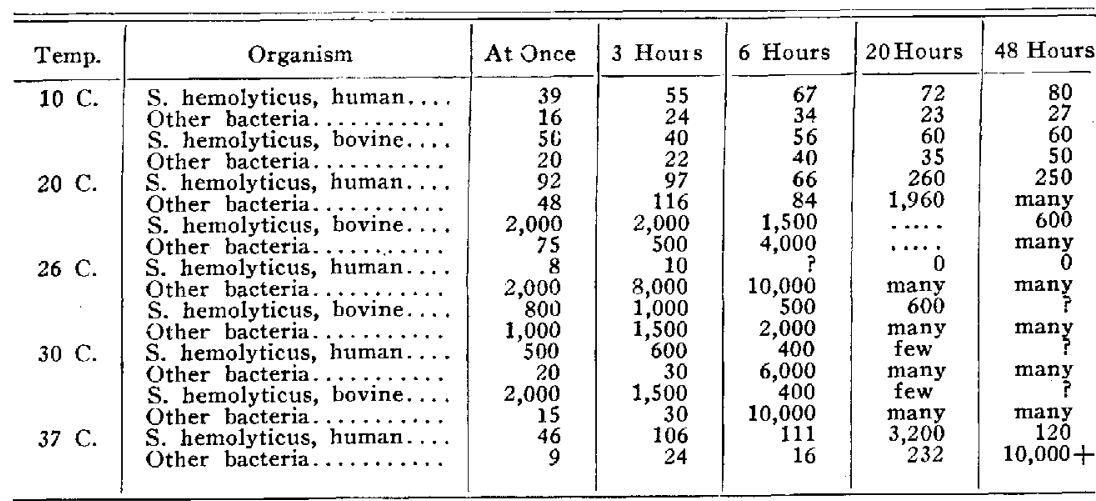

At $10 \mathrm{C}$. no appreciable increase occurs in any of the strains tested; at $20 \mathrm{C}$. at the end of forty-eight hours there is some increase in the hemolytic streptococci of human and bovine origin, but little or none at the end of twenty hours. The streptococcus lacticus, however, grows well, and even at the end of three hours has multiplied considerably. At $26 \mathrm{C}$. there is naturally greater multiplication of all strains than at $20 \mathrm{C}$., but it should be noted that the hemolytic streptococci are slow in proliferating, for, even at the end of six hours, they have not increased appreciably. At $30 \mathrm{C}$. and at incubator temperature ( $37 \mathrm{C}$.), rapid development of all strains takes place as wotld be expected. Even at $37 \mathrm{C}$., little or no multiplication occurs in milk 
at the end of one or two hours, but at the end of three hours marked development is going on.

The effect of the contaminating germs in commercial milk on the growth of hemolytic streptococci, evidently of importance, was next considered. To determine this effect, hemolytic streptococci were added to ordinary commercial, pasteurized milk, the tubes being placed at various temperatures and blood agar plates inoculated at frequent intervals with comparable quantities. The results are given in Table 2 . Before the addition of hemolytic streptococci, there were in the commercial milk used in this experiment 5,000 bacteria per c.c., including streptococcus lacticus, colon bacillus, bacillus lactis aerogenes and a few staphylococci, but no hemolytic streptococci.

In ordinary pasteurized milk it is uncommon to find hemolytic streptococci. In plating out samples of such milk, I have olsserved occasional colonies only. If the pasteurization is efficient, these germs should all be killed since they are readily destroyed, as I have repeatedly observed, at a temperature of $60 \mathrm{C}$. for twenty minutes. Their presence, therefore, probably means either inefficient pasteurization or stubscquent contamination. It is perhaps possible that strains of hemolytic streptococci do exist which resist this temperature but I have not encountered such. Indeed, their thermal death point is usually considerably below $60 \mathrm{C}$; $54 \mathrm{C}$. is given by Sternberg and others. I have not systematically examined non-pasteurized market milk for these organisms but it is known, of course, that they are found every now and then in such milk. There is considerable data in the literature on the presence of streptococcus pyogenes in milk and probably many of these strains, but not all, were hemolytic in character.

TABLE 3

Effect of Buttermilk on Hemolytic Streptococci (Bovine Strain) at $37 \mathrm{C}$.

\begin{tabular}{|c|c|c|c|}
\hline & & Buttermilk & Neutralized Buttermilk \\
\hline $\begin{array}{rl}0 & 1 \\
3 & 1 \\
6 & 1 \\
24 & 1 \\
72 & 1 \\
96 & 1 \\
144 & 1 \\
168 & 1 \\
192 & 1 \\
240 & 1 \\
264 & 1 \\
312 & 1\end{array}$ & 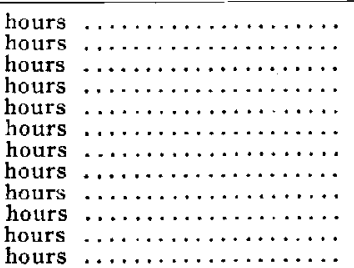 & $\begin{array}{r}1,000 \\
0 \\
0 \\
0 \\
0 \\
0 \\
0 \\
0 \\
0 \\
0 \\
0 \\
0\end{array}$ & $\begin{array}{r}10,000 \\
1,500 \\
10,000 \\
\text { many } \\
10,000 \\
10,000 \\
128 \\
600 \\
40 \\
2 \\
3 \\
0\end{array}$ \\
\hline
\end{tabular}

It is seen from this table that at $20 \mathrm{C}$. there is little or no increase in the hemolytic streptococci, but marked increase of other bacteria (many of them streptococcus lacticus). At the higher temperatures, also, the contaminating bacteria rapidly proliferate while the hemolytic 
streptococci either do not grow at all or are apparently killed. In some of the tubes, there was certainly some increase of the streptococci in the first twenty hours. Later, there was a decrease or an entire disappearance. It is not always easy to determine exactly at what point they are all killed; at times one must make many plates and many dilutions in order to isolate the streptococci. It will be seen, then, from this table that as the temperature increases, the rapid growth of the contaminating bacteria very largely checks the growth of the hemolytic cocci, which, in their absence as shown in Table 1, would develop rapidly.

TABLE 4

Effect of Souring Milk on the Virulence of Streptococct

Temperature $20 \mathrm{C}$.

\begin{tabular}{|c|c|c|c|}
\hline $\begin{array}{l}\text { At once } \\
24 \text { hours } \\
48 \text { hours } \\
72 \text { hours } \\
96 \text { hours }\end{array}$ & $\begin{array}{c}\text { S. hemolyticus } \\
1,000 \\
1,000 \\
\frac{800}{400}\end{array}$ & $\begin{array}{c}\text { Other bacteria } \\
20 \\
10,000 \\
\text { Many } \\
\text { Many }\end{array}$ & $\begin{array}{l}\text { Inoculation of Rabbit } \\
\text { Death in } 36 \text { hours } \\
\text { Death after } 48 \text { hours } \\
\text { Died at once from }\end{array}$ \\
\hline $\begin{array}{c}120 \text { hours } \\
148 \text { hours } \\
9 \text { days }\end{array}$ & $\begin{array}{r}50 \\
50 \\
\text { None }\end{array}$ & $\begin{array}{l}\text { Many } \\
\text { Many } \\
\text { Many }\end{array}$ & $\begin{array}{l}\text { embolism } \\
\text { No effect } \\
\text { No effect }\end{array}$ \\
\hline
\end{tabular}

Temperature $27 \mathrm{C}$.

\begin{tabular}{c|c|c|c}
\hline At once & S. hemolyticus & Other bacteria & $\begin{array}{c}\text { Inoculation of Rabbit } \\
\text { Joint lesion in 3 days. } \\
\text { Death in 2 weeks } \\
\text { Joint lesion in 3 days. } \\
\text { Death in 16 days } \\
\text { No effect }\end{array}$ \\
48 hours & 2,000 & 15 & No effect \\
72 hours & 12 & 8,000 & Many \\
96 hours & 2 col. & Many & - \\
120 hours & Maurs \\
9 days & - & - & - \\
\hline
\end{tabular}

The same result is obtained also by testing the growth of hemolytic streptococci in sour milk and buttermilk which have been rendered sterile by heat. Table 3 shows the effect on streptococci of plain sterile buttermilk and of sterile buttermilk which has been brought to the neutral point or slightly beyond with $\mathrm{NaOH}$. In the acid milk all the hemolytic streptococci were dead in three hours. The same milk neutralized, furnished a good medium in which they thrived for several days after which time they gradually died out. The same would probably be true of cottage cheese made with sour milk. Such rapid 
destruction of cocci as indicated in this table will be obtained only if the milk has been allowed to sour at room temperature $(20-22 \mathrm{C}$.) for forty-eight hours or longer after curdling.

In order to further test the effect of souring on streptococci, milk, to which these organisms had been added, was injected into rabbits at intervals as the souring process went on. In one series the milk was kept at $20 \mathrm{C}$. and another at $27 \mathrm{C}$. Bacterial counts were also made. The results are given in Table 4 . It will be seen that after a relatively short interval, depending on the temperature, the streptococci in such milk lose their virulence for rabbits. During this time the hemolytic streptococci have decreased while the contaminating germs have increased markedly. The rabbits were all injected with 3 c.c. of milk. The figures in the table represent the number of organisms in one standard loop of the same milk. The injections must be made very carefully and slowly, otherwise death will occur from embolism.

The effect of butter on the viability of hemolytic streptococci was determined and the results are given in Table 5. The butter used was ordinary commercial butter purchased from a large dairy firm. To this the streptococci were added in sufficient quantity so that a standard loop contained about 5,000 organisms. The plain butter which is acicl in reaction was tested, as was also some of the same butter after careful neutralization with $\mathrm{NaOH}$. It will be seen from the table that in the plain butter there is a rapid decrease in the number of streptococci and a more moderate decrease in other organisms. Ordinarily, all have disappeared entirely after seventy-two to ninety-six hours. Several experiments of this kind show that there is some variation in the time of disappearance, but as a rule, it is approximately as represented in the table. In the neutralized butter the hemolytic streptococci live much longer and there may be a slight increase, but later they decrease. The other bacteria also tend to increase and in some of the experiments this increase was marked. It would seem then that a large part of the decrease of organisms in butter on standing is due to the acidity.

Both home-made and commercial ice-cream were tested with respect to the viability of hemolytic streptococci. The former was made with milk and eggs and a small amount of sugar and the streptococci were added before freezing. No hemolytic streptococci of any kind were present before, as shown by careful plating. The commercial ice-cream was purchased from a small dealer. It contained 
many bacteria, but no hemolytic streptococci. Some of the frozen cream was softened and after adding the streptococci, it was frozen again. Plates were made at intervals of one to three days for eighteen days. During this time the samples of ice-cream were kept firmly frozen. The results are given in Table 6. Practically no change appeared in the number of streptococci or in the number of other organisms during the entire period. It was furthermore shown by inoculation that the hemolytic cocci retained their virulence during this period.

TABLE 5

Effect of Butter on Hemolytic Streptococci at Room Temperature

\begin{tabular}{|c|c|c|c|c|c|c|c|}
\hline \multicolumn{6}{|c|}{ Plain Butter } & \multicolumn{2}{|c|}{ Neutralized Butter } \\
\hline Organism & $\begin{array}{c}\text { S. hemolyticus, } \\
\text { human }\end{array}$ & Other & bacteria & $\begin{array}{c}\text { S.hemolyticus, } \\
\text { bovine }\end{array}$ & Other bacteria & $\begin{array}{c}\text { S.hemolyticus, } \\
\text { human }\end{array}$ & Other bacteria \\
\hline $\begin{array}{l}\text { At Once } \\
24 \text { Hours } \\
48 \text { Hours } \\
72 \text { Hours } \\
96 \text { Hours } \\
148 \text { Hours } \\
192 \text { Hours } \\
240 \text { Hours } \\
288 \text { Hours } \\
408 \text { Hours }\end{array}$ & $\begin{array}{r}5,000 \\
3,000 \\
80 \\
0 \\
0 \\
= \\
= \\
=\end{array}$ & & $\begin{array}{l}76 \\
10 \\
12 \\
12 \\
20 \\
= \\
= \\
= \\
=\end{array}$ & $\begin{array}{r}5,000 \\
6,000 \\
-25 \\
1 \\
0 \\
= \\
=\end{array}$ & $\begin{array}{l}500 \\
600 \\
- \\
\text { Few } \\
\text { Few } \\
\text { Few } \\
= \\
= \\
=\end{array}$ & $\begin{array}{r}5,000 \\
6,000 \\
5,000 \\
8,000 \\
6,000 \\
150 \\
60 \\
100 \\
0\end{array}$ & $\begin{array}{r}50 \\
100 \\
200 \\
300 \\
1,000 \\
\text { Many } \\
\text { Many } \\
\text { Many } \\
\text { Many }\end{array}$ \\
\hline
\end{tabular}

TABLE 6

Viability of Hemolytic Streptococci in Ice Cream

\begin{tabular}{|c|c|c|c|c|c|c|}
\hline & \multicolumn{3}{|c|}{ Home-Made Ice Cream } & \multicolumn{3}{|c|}{ Commercial Ice Cream } \\
\hline & $\begin{array}{l}\text { S. hemolyticus, } \\
\text { human }\end{array}$ & Other & Bacteria & S. hemolyticus, & Other & Bacteria \\
\hline $\begin{array}{l}\text { Before freezing } \\
\text { Just after freezing } \\
24 \text { hours } \\
48 \text { Hours } \\
72 \text { Hours } \\
120 \text { Hours } \\
168 \text { Hours } \\
216 \text { Hours } \\
12 \text { Days } \\
15 \text { Days } \\
18 \text { Days }\end{array}$ & $\begin{array}{l}6,000 \\
5,000 \\
5,000 \\
6,000 \\
5,000 \\
8,000 \\
8,000 \\
6,000 \\
6,000 \\
5,000 \\
4,000\end{array}$ & & $\begin{array}{r}30 \\
50 \\
25 \\
10 \\
200 \\
100 \\
100 \\
10 \\
4 \\
5 \\
8\end{array}$ & $\begin{array}{l}6,000 \\
5,000 \\
4,000 \\
4,000 \\
6,000 \\
7,000 \\
5,000 \\
4,000 \\
4,500 \\
3,500\end{array}$ & & $\begin{array}{r}-100 \\
50 \\
200 \\
250 \\
400 \\
60 \\
-50 \\
200 \\
\end{array}$ \\
\hline
\end{tabular}

When cream is separated from milk by centrifugal force, the hemolytic streptococci behave as other bacteria, that is, some are carried upward by the oil droplets and others are thrown down, the 
result being that the cream and sediment contain many more cocci than the milk. The skim-milk is not deprived entirely of the streptococci, but contains decidedly less than the cream or the sediment. The following figures obtained by experiment fairly represent the distribution of hemolytic streptococci per 0.1 c.c. in the various portions. Whole milk before centrifugation, 2,000; after centrifugation, cream, 10,000; sediment, 50,000; skim-milk, 600. These figures in a general way, agree with the figures obtained by others as regards the distribution of bacteria of various kinds in cream and skim-milk.

The following deductions, I think, may be made from the data obtained. Hemolytic streptococci do not multiply practically at all at $20 \mathrm{C}$; ; as the temperature is raised to a point where they thrive, other organisms, always present in commercial milk, grow so much more rapidly and produce acid to such an extent that the streptococci very soon not only are inhibited in their growth, but killed. Furthermore, exposure of hemolytic streptococci in milk to the optimum temperature for one to two hours will result in little or no multiplication. Hence there can be no appreciable increase of streptococci, either while milk. is being cooled or in the heating or cooling of milk during the process of pasteurization. It is evident, too, that under the conditions which ordinarily prevail in the handling of milk, no matter how unsanitary, these streptococci cannot develop to any great extent; that is, streptococci coming from the hands or the throat of a milker or a milkhandler, would multiply little or not at all in the milk. This fact should be considered in its bearing on the causation of milk epidemics of sore throat. The character of these epidemics, their explosive onset, etc., suggest that the infectious organisms are probably present in large numbers and that the persons infected have probably taken large doses of the cocci. This would not so readily occur if the origin is from the hands or the throat of a milk-handler. On the other hand, it is readily explained on the assumption that the infectious agent comes directly from the cow. In the milk of cows suffering from mastitis there may be enormous numbers of hemolytic streptococci. Actual count in one instance gave 200 million hemolytic streptococci per c.c. of ropy milk as it came from the udder. This means that one pint of such milk contains 100 billion streptococci, which is about equivalent to the number of streptococci grown on 100 ordinary blood-agar slants. Of course, it is true that the cocci are not always present in such numbers 
in infected milk, and furthermore, milk from a diseased cow, if it is used, is mixed with milk from the entire dairy, which means considerable dilution.

It is of course not impossible for milk to become dangerously infected by a milker or a milk-handler. Streptococci from such a source may get into the milk and if sufficiently virulent, tho few in number, may undoubtedly cause the disease. In other diseases like diphtheria, typhoid fever and scarlet fever, which at times are transmitted through milk, it is apparently true that comparatively few germs entering the milk are sufficient to transmit the disease. In seeking the source of contamination in any milk epidemic, therefore, the possibility of infection from a human carrier as well as infection from a diseased cow should always be considered. Furthermore, every investigation into the cause of an epidemic should not only look especially into these two possible sources, but should also consider other means of transmission, even tho remote or hypothetical, such as food, water, animals, insects, etc. The exact rôle of personal contact in all epidemics of sore throat should also be carefully analyzed.

\section{SUMMARY}

In the process of milk-souring the growth of hemolytic streptococci is inhibited and the organisms are gradually destroyed. They are killed in three hours or less by the acidity of sour milk (forty-eight hours after curdling) and of buttermilk. In ordinary butter they die in the course of a few days, due to the acidity, altho in neutral butter they live for a long time.

In ice-cream, hemolytic streptococci remain alive for at least eighteen days without any appreciable diminution in number or virulence. Ice-cream would seem to be, therefore, a most suitable medium for the transmission and preservation of dangerous streptococci.

Separator-cream contains more streptococci than the whole milk, skim-milk considerably less, while the sediment contains a large number.

Hemolytic streptococci do not multiply to any extent at $20 \mathrm{C}$. or below in milk; at $26 \mathrm{C}$. there is little or no multiplication during the first six hours in sterile or commercial milk, but at the end of twenty hours there is considerable increase in the sterile milk. In the commercial milk their growth is inhibited by the growth of other bacteria; this holds also for higher temperatures. 
It seems that under no conditions met with in the ordinary handling of milk can there occur any appreciable multiplication of hemolytic streptococci.

Inasmuch as under the most favorable temperature, multiplication of hemolytic streptococci in milk does not occur inside of one to two hours, it is impossible for any appreciable increase to occur during the short interval between the raising and lowering of the temperature of milk in the process of pasteurization. 